\title{
Slovar členkov kot živa vez med besedilom in slovarjem
}

\author{
ANDREJA ŽELE \\ Filozofska fakulteta Univerze v Ljubljani, Aškerčeva 2/II, \\ SI-1000Ljubljana, andreja.zele@ff.uni-lj.si
}

\begin{abstract}
Teoretično-praktična predstavitev členka kot dinamične funkcijske besede in stavčnega modifikatorja združuje in komentira sodobne jezikoslovne predpostavke o členku in praktični oz. slovarski prikaz rabe členkov v slovenskih besedilih.

This article posits a theoretical-practical depiction of the particle as a dynamic function word and sentence modifier. The research brings together and provides commentary on contemporary linguistic assumptions about the particle and the practical, or lexical, display of how particles are used in Slovenian texts.
\end{abstract}

Ključne besede: členek, funkcijska beseda, naklonska in povezovalna vloga členkov, besedilo, slovar

Key words: particle, function word, mood and connecting roles of particles, text, dictionary

\section{0 členku $z$ vidika slovanskega in slovenskega jezikoslovja ${ }^{1}$}

Ko govorimo o aktualnem razmerju med besedilom in slovarjem in obratno, so zelo bistvena sestavina jezika členki, saj označujejo vsebino razmerij. Prav pod geslom »besedilo v slovarju in slovar v besedilu« nastaja slovar členkov.

\footnotetext{
${ }^{1}$ Za sintezo dosedanjih ugotovitev o slovenskem členku sem upoštevala in komentirala ugotovitve sodobnih slovenskih jezikoslovcev: J. Toporišič (1991, 2000), I. Černelič Kozlevčar (1992), A. Vidovič Muha (1984, 2000), A. Skubic (1999), in zlasti ugotovitev iz sodobnih anglo-ameriških, ruskih, čeških in slovaških slovnic (citirani so v besedilu in v zbrani literaturi na koncu razprave).
} 
V slovanskem jezikoslovju so členki pomenljivo označeni kot stavčni prislovi, ${ }^{2}$ kar jih hkrati uvršča v besedilno besedno vrsto. V ospredju je torej njihova vloga $\mathrm{v}$ besedilu oz. besedilna funkcija, zato so samo funkcijska beseda in slovarske razlage za členke so (samo) funkcijske; leksikografsko lahko členek opredelimo kot ubesedeno (slovarsko) referenco z govornim dejanjem. Dodatno poudarjanje funkcijskosti členkov je tudi trditev, da so členki posledica pomenskega praznjenja besed, in tako ohranjajo samo še vlogo pomenskega niansiranja sledečih določevanih besed, tj. izražajo in določajo zgolj spremne okoliščine najbližjim polnopomenskim besedam.

Členek je opredeljen tudi kot strnjeni/zgoščeni ubesedeni govorni dogodek (t. i. besedilni/stavčni skrček), ki opozarja na spremene okoliščine besedila, saj s členki zlasti govoreči vzpostavlja stik s potencialnim naslovnikom. S sporočanjsko-pragmatičnega vidika se členki se delijo na dve krovni skupini, in sicer na povezovalne členke (s poudarkom na besedilnih razmerjih) in naklonske (s poudarkom na medosebnih razmerjih).

Povezovalni členki (P) poudarjajo besedilno koherentnost in kohezivnost in v tem smislu se delijo še na podskupine: dodajalni (Pd: celo, kaj šele, še več), izbirni (Pizbir: drugače, sicer pa), izvzemalni (Pizvze: edino, le, sicer (pa)), navezovalni oz. nadaljevalni (Pnavez: kakorkoli (že), najsibodi, potemtakem, vendarle, vsekakor), nadomestni (Pnadom: namesto tega, nasprotno), nasprotovalni (Pnaspr: zato pa), pojasnjevalni (Ppojas: to se pravi, torej), ponazarjalni (Pponaz: namreč), popravni (Ppoprav: ali bolje, namreč, oziroma), poudarni (Ppoudar: pravzaprav, predvsem, vsaj, zlasti), povzemalni (Ppovze: skratka, torej), zastranitveni (Pzastr: mimogrede). Naklonski členki (N) pa se osredotočajo bodisi na udeležence, na okoliščine, na glagolski proces ali na količino in obsegajo štiri večje podskupine: čustvenostni (Nč: bogvaruj, končno, saj, začuda), pozivni (Np: dejansko, kajne, naj, mar), vrednotenjski (Nv: baje, morda, navsezadnje, nemara, takorekoč, verjetno) in členki zanikanja (Nn: nikar). Tako naklonski kot povezovalni členki niso deli propozicije, temveč jo le modificirajo, zato so označeni kot modifikatorji.

Poudarjena navezovalna oz. povezovalna vloga členkov vzpostavlja skladenjskopomenska razmerja s sobesedilom oz. pri govoru tudi situacijska razmerja z okoliščinami razumevanja, tako da so skladenjskopomenska sprevračanja med naklonsko in povezovalno vlogo zelo pogosta in navadna, kar členke funkcijsko približuje veznikom. Nekaj primerov prevladujoče vezniške rabe členkov sem povzela že iz zgornjih izpisov: Potem bi se vrnila. Seveda sama, Boji se zveri.

Kajpada medvedov tudi.

Po pričakovanju pa prevladujejo naklonski členki, saj je naklonskost v procesu upovedovanja njihova prvotna vloga: Kdor ne najde nobene povezave, se seveda moti (s prevladujočo pomensko sestavino (PS) 'čustvenosti'), Stari Marinč je bil kajpa slep in gluh /.../, Vrata bodo seveda odklenjena (s prevladujočo

\footnotetext{
${ }^{2} \mathrm{O}$ členkih kot o stavčnih prislovih »rečenični prilozi« z vidika pragmatične obravnave modalnosti govori tudi že Milka Ivić (1973: Problematika modalnih rečenica. V: Otázky slovanské syntaxe. Roč. III. Brno: J. E. Pukryne. 85-91).
} 
PS 'pritrjevanja'), Bržkone so to pobožne želje nekaterih ljudi (s prevladujočo PS 'verjetnosti'), To je pravzaprav njena edina sreča (s prevladujočo PS 'domneve'), Našli so pravzaprav samo še eno truplo (s prevladujočo PS 'zadržka').

$\mathrm{V}$ ospredje stopajo razodevalna, pozivna in stikovna besedilna vloga, ki so neke vrste čustvenostna/naklonska nadgradnja samoumevni prikazovalni vlogi predmetnosti in pojavnosti. (Našteti so od najpogostejšega proti manj pogostemu): a1) 'podkrepitev trditve' (Tako dobro se ti seveda ne bo več godilo; Ne bom več toliko delal, primojsvet da ne); a2) 'podkrepitev-zanikanje' (To je storil vragvedikdo, Vragvedi, če je še kaj varno); b) 'zanikanje' (Bogvaruj povedati komu; Vseeno, morali bi si vzeti čas); c) 'opozorilo' (Bogvaruj da bi se mu približal); č) 'poziv' (Ali bo kaj?!); d) 'omejitev' (Zamisel je resda dobra, samo izvedljiva $n i) ; \mathrm{d}_{1}$ ) 'omejitev na pomembnost' (Bil je predvsem miren); $\mathrm{d}_{2}$ ) 'omejitev na popolnost' (Bil je povsem miren); e) različna čustvena stanja: $\mathrm{e}_{1}$ ) 'želja' (To bo zdaj le v redu); $\mathrm{e}_{2}$ ) 'gotovost' (Zagotovo bo boljše!).

Naklonski členki (N), ki se osredotočajo bodisi na udeležence, na okoliščine, na glagolski proces ali na količino, obsegajo štiri večje podskupine: čustvenostni (Nč: bogvaruj, končno, saj, začuda), pozivni (Np: dejansko, kajne, naj, mar), vrednotenjski (Nv: baje, morda, navsezadnje, nemara, takorekoč, verjetno) in členki zanikanja (Nn: nikar).

\section{0 členkih z leksikološkega in leksikografskega vidika}

Pri slovarski obdelavi členkov je upoštevana leksikografska obdelava členkov G. Helbiga $\left({ }^{2} 1990\right) \mathrm{z}$ upoštevanjem slovarskega (SSKJ, SP) in aktualnega korpusnega gradiva; pomen in posledično funkcijskost členkov pa dodatno osmišljajo etimološke osvetlitve dr. Marka Snoja. Za slovaropisno obravnavo členka je bil izdelan računalniški program, tako da slovar nastaja v okviru spletnega slovarskega portala Termania.

Nekaj tipičnih členkov je vzorčno in primerjalno, tudi glede na različno pogostnost rabe (po Nova beseda, Fidaplus in Gigafida), leksikografsko prikazanih z upoštevanjem najbolj poudarjenih skladenjskopomenskih vlog znotraj krovnih naklonske vloge $(\mathrm{N})$ in povezovalne vloge $(\mathrm{P})$.

Obravnava členkov v slovarskem članku se lahko razdeli v pet osnovnih polj: 1) povezovalna $(\mathrm{P})$ ali naklonska $(\mathrm{N})$ vloga členkov, 2) funkcijska razlaga $\mathrm{z}$ uvajalnimi tipskimi glagoli: izraža, krepi, omejuje, opozarja, poudarja, stopnjuje, utemeljuje, uvaja, 3) mesto oz. položaj v besedilu - nanašanje na besedo, del povedi ali na celo stavčno poved, 4) zgledi s stavčnimi ustrezniki, 5) možna sinonimija in 6) etimološka razlaga (E:). Leksikografska oz. leksikološka predstavitev je ravno zaradi upoštevanja vseh zgoraj naštetih meril lahko še najbolj celostno funkcijsko in pomenskorazmerno ovrednotenje členkov.

mordà tudi mórda [ä; ộ] 1. Nv izraža verjetnost, ne popolno prepričanost o čem: Rad bi vedel, če me morda še pozna; Zvečer se morda vidiva; Mislim, da bo tokrat šlo. 
Morda. |Upajmo?!|; Morda se vendar vrneš domov |Obstaja možnost, Možno je| // izraža sklepanje: Draži jo morda ne iz hudobije, ampak iz prešernosti |Da se sklepati|; sin. morda, morebiti 2. Nv izraža približno najvišjo mero povedanega: Dosti ni popil, tri kozarce morda $\mid Z d i$ se / Kaže, da ...|; sin. kvečjemu 3. Nč v zvezi z bi izraža obzirno željo, zapoved: Morda bi se pomaknili nekoliko naprej; morda bi še enkrat začeli |Ali je možno, Bi bilo možno| 4. Np izraža vljudnostno in obzirno vprašanje, prošnjo: Bi morda še kaj popili; Ali bi morda kaj prispevali? |Smemo upati, da bi ...| 5. Nv v retoričnem vprašanju poudarja nasprotno trditev: Kdo me bo strahoval, morda ti, ki te nič ni! |Kaj si domišljašs; sin. màr

E: = hrv., srb. mòžda iz *možeţ da iz 3. osebe ednine glagola môči in veznika da

\section{samó [ộ]}

I. N 1. Nv izraža omejeno vrednotenje na navedeno: Cele dneve samo dela $\mid \mathrm{Ne}$ počne drugega|; Ambulanta sprejema samo nujne primere |Drugih ne|; Ambulanta samo sprejema, obravnavo pa opravijo na polikliniki |Nima drugih pristojnosti| // izraža popolno omejenost na navedeno dejanje: Lahko je samo gledal, kako vse propada |Ni imel druge možnosti|; Hotel je samo jesti in jesti |Nič drugega kot|// v zvezi s pa krepi nasprotje s prej povedanim: Starši so kupovali zemljo, otroci pa jo samo prodajajo |Drugega niso zmožni| sin. lè 2. Nv z vprašalnim zaimkom ali prislovom izraža ugibanje: Samo kaj si bodo mislili o nas; Pride. Samo kdaj |Lahko le ugibamo|; sin. lè 3. Nv v zvezi s če poudarja pogojenost: Naj se igrajo, samo če ne bodo delali prevelikega hrupa; Samo če si res pripravljen, se prijavi k izpitu |Pod pogojem, da|; sin. lè 4. Np z velelnikom izraža spodbudo, poziv: Samo ne izgubite živcev; Samo nič ne jokaj; Samo poglejte, kako je lepo; Samo mirno; Samo na dan z besedo |Potrudite se in ..., Potrudite se da, ...; sin. lè 5. Np izraža grožnjo, svarilo: Samo počakaj, te bom že ujel; Samo poskusi, pa boš videl; Samo še enkrat |Če si upaš|; sin. lè 6. Np izraža ukaz, željo: Samo da boš priden; Samo da bi ga pregovoril; Če bi se samo dalo kam skriti |Želi, Upa| 7. Nč krepi intenzivnost dejanja, visoko pozitivno stopnjo: Samo čakajo, da planejo po njem; To je stanovanje, kot si ga lahko samo želiš |Upajo na priložnost| 8. Nč izraža obžalovanje: Odličen delavec je, samo kaj, ko pa nima več ne dela ne zdravja |To ni dovolj| 9. Nč v zvezi z da, če izraža zadovoljnost, začudenje, zaskrbljenost: Samo da ste zdravi; Samo da se ji ni kaj zgodilo |Najpomembneje je|

II. P 1. Pnaspr uvaja nasprotje s prej povedanim: Je priden delavec, samo izkušnje mu manjkajo; Govori lepo, samo malo pretiho; Vlaki prihajajo, samo z zamudo; Z vami grem, samo, ali je potrebno; Lepo se sliši, samo, ali je res |Vendar (pa)|; sin. vèndar 2. Pizvze z nikalnico poudarja izvzemanje: Vsi vedo, samo ona ne |Le|; Lahko da boš od koga izvedel, samo od mene ne; Te mravlje so podobne našim, samo ne po velikosti; Bodi prizanesljiv, samo ne preveč |Vendar (pa)|// v zvezi samo da omejuje prej povedano: $\mathrm{Na}$ dopustu nam je bilo zelo lepo, samo da je bilo včasih prevroče |Vendar (pa)|; Ne zmeni se, če drugi trpijo, samo da gre njemu dobro; Takoj pridem, samo da se oblečem $|\mathrm{Le}| \mathbf{3}$. Ppoudar v zvezi ne samo - ampak tudi stopnjuje prej povedano: Dobil je ne samo smuči, ampak tudi drsalke; Zame bi bila to ne samo sreča, ampak tudi čast |Ni se ustavil pri| 4. Pnavez opozarja, da se dejanje v nadrednem stavku zgodi neposredno za dejanjem v odvisnem stavku: Samo prikaže se v javnosti, že pišejo o njej; Samo sede, pa ga spet pokličejo |Dovolj da, Ko| // v zvezi s tako uvaja omejenost na navedeno: Samo tako boš dosegel, kar hočeš |Ni izbire, Ni drugih možnosti|

E: iz zaimka sám (= stcslov. samъ, hrv., srb. sâm, rus. sám, češ. sám), nastalega iz pslov. *samb iz ide. *sōmo- »ki pripada istemu« iz *somo- »isti, enak« 
sevéda [ệ]

I. N 1. Nv izraža samoumevnost trditve: $Z$ njegovim mnenjem se seveda ni mogoče strinjati; $S$ tem pa seveda ni rečeno, da je kriv; Ti se ga boš seveda še spomnil; Pomeni se s sosedom, seveda mirno, brez prepira $\mid$ Razume se, da ...|; sin. sevé, véšda 2. Nč izraža soglasje, pritrditev, pritrjevanje brez pridržka: Seveda, vem, da je hudo; Hočeš požirek vina? Seveda, kar natoči mi ga!; Ali misliš, da se nam bo posrečilo? Seveda, seveda |Prav nič ne dvomim, Tu ni dvoma!, To je gotovo!|; sin. gotôvo, zagotôvo 3. Nn izraža močno zanikanje, zavrnitev: Seveda, še nagrado bi rad! |Kar misli, domišljaj si!, Niti v sanjah!, Ne pride v poštev!|; sin. kájpada

II. P 1. Pd izraža zadržek: Vse imam, kar potrebujem. Seveda mi pa še nekaj manjka |Lahko pa se razume, da ...| 2. Ppoudar opozarja na prehod k drugi misli: Seveda je poleg luči pomembna sestavina Župančičeve poezije tudi tema |Moramo še poudariti, da ...|

E: sklop iz splošnovršilskega se, 3 . osebe ednine glagola védeti in veznika da

\section{verjétno [é]}

Nv izraža precejšnjo prepričanost o možnosti ali nemožnosti česa: Ni prišel, verjetno je zaspal; Zelo verjetno je, da pride jutri |Po vsej verjetnosti, Precej mogoče je, da ...|// izraža zadržano pritrjevanje: Boste šli? Verjetno |Skoraj gotovo|; sin. mogóče

E: konvertirano iz prislova verjétno iz pridevnika verjéten iz glagola verjéti

\section{Sklep}

Skratka, z vidika razmerja besedilo - slovar in obratno si je potrebno uzavestiti čimveč jezikovno-pragmatičnih možnosti. Razmerje do povedanega in do okoliščin govornega položaja sploh izražajo členki, zato so funkcijsko zelo žive sestavine jezika vsakdanjega sporazumevanja, ki s svojo pomenskorazmerno vlogo aktualizirajo ubesedeno in hkrati besedila tudi sporočilno zgoščajo.

\section{VIRI IN LITERATURA}

Milka IVIĆ, 1973: Problematika modalnih rečenica. Otázky slovanské syntaxe. Roč. III. Brno: J. E. Pukryne. 85-91.

Ivanka ČERNELIČ-KOZLEVČAR, 1992: O delitvi členkov. Vprašanja slovarja in zdomske književnosti. Ljubljana: Slavistično društvo Slovenije. 213-227.

Andrej SKUBIC, 1999: Ogled kohezijske vloge slovenskega členka. Slavistična revija 47/2, 211-238.

Jože TOPORIŠIČ, ${ }^{1} 1976,{ }^{4}$ 2000: Slovenska slovnica. Založba Obzorja Maribor.

Jože TOPORIŠIČ, 1991: Členki in njihovi stavčnočlenski ustrezniki. XXVII. Seminar SJLK. Ljubljana: FF. 3-16.

Ada VIDOVIČ MUHA, 1984: Nova slovenska skladnja J. Toporišiča. Slavistična revija $32 / 2,142-155$. 
Ada VIDOVIČ MUHA, 2000: Slovensko leksikalno pomenoslovje. Govorica slovarja. Ljubljana: Znanstveni inštitut.

\section{DICTIONARY OF PARTICLES AS A LIVING LINK BETWEEN THE TEXT AND DICTIONARY}

In order to have clear and effective communication one needs to keep open as many linguistic and pragmatic options as possible and utilise them in the formation of texts in the context of normative-stylistic requirements. The relation to what is being said and the circumstances of the spoken situation are expressed chiefly through particles, which is why they are functionally very lively language components of everyday communication. With their semantic-contextual role they actualise what is worded and at the same time condense the message. The particle is one of those non-parts-of-speech that fulfils the textual role of the connector and is ranked among inter-predicate connectors or the connectors in supra-predicate texts. Since particles play primarily a textual role, they are also particularly meaningful words, which can be reasonably used in a text, especially in one's first language; they maintain a strong communicative (connective) role and a well-marked role of influence. From the communicative-pragmatic perspective, particles are divided into two main categories, namely the connecting (text) particles resulting from pragmatic circumstances, and mood (interpersonal) particles resulting from communicative relationships. Mood particles focus either on the participants, the circumstances, the verbal process, or the quantity, e. g. bogvaruj, končno, dejansko, baje, nikar, while the connecting particles highlight textual coherence and cohesion, e. g. celo, kaj šele, drugače, sicer pa, torej, etc. The most comprehensive and functional semantic-circumstantial evaluation of particles can be found in lexical representation. 